\author{
仙波卓 弥*1, 濱口 元 基*2, 原田武志*2

\section{Development of Electroformed Diamond Tool Strengthened by Synthesized Intermetallic Alloy}

\author{
Takuya SEMBA*3, Motoki HAMAGUCHI and Takeshi HARADA \\ ${ }^{* 3}$ Faculty of Engineering, Fukuoka Institute of Technology, \\ 3-30-1 Wajirohigashi, Higashi-ku, Fukuoka-shi, Fukuoka, 811-0295 Japan
}

\begin{abstract}
An electroformed diamond tool with superior proportional limit and wear resistance was developed for the microgrinding of hard and brittle materials, in which a tool of small diameter is rotated at a high speed. A plating rig that can fabricate an electroformed diamond tool with fine diamond grains and an electrodeposited $\mathrm{Ni}$ grain size less than $2 \mathrm{~nm}$ was newly developed. A thermal etching for roughening diamond grain surfaces was conducted to increase gripping strength between diamond grains and the bond material $\mathrm{Ni}$ of the tool. In addition, an annealing process to synthesize the intermetallic alloy $\mathrm{Ni}_{3} \mathrm{P}$ was used on the tool not only to increase the hardness of the bond material but also to increase the proportional limit of the tool. It was verified through the bending test that both the Young's modulus and proportional limit of the tool increased to about $40 \mathrm{GPa}$ and $1.5 \mathrm{GPa}$, respectively, using thermally etched diamond grains and annealing tools, compared with those of electroformed diamond tools fabricated using conventional techniques.
\end{abstract}

Key Words: Nano \& Micro Machining, Grinding, Grinding Wheel, Abrasive Grain, Electroformed Diamond Tool

\section{1. 緒言}

マイクロ切削加工と異なり，マイクロ研削加工は硬 脆材料に対して超精密・微細形状を造りうる能力を持 っている.しかし，微小径の切削工具を高速回転させ て使用する方式でのマイクロ切削加工(1) が多用され ているのに対し，同方式でのマイクロ研削加工は実用 化されていない.

この背景には, 耐欠損性や耐摩耗性に優れた工具の 開発が遅れていることが影響しているように考えられ る.すなわち, 既存の研切削工具の中では電着工具が 最も耐摩耗性に優れているが工具寿命が短いという問 題点を抱えており ${ }^{(2)}$ ，実用に耐える研削工具は普及し ていないのが現状である。

このような背景を踏まえ, 市販の電着工具に勝る耐 摩耗性を持つ電鋳工具の開発を行ってきた. とくに前 報(3)では，電気めっき法を用いた上で電析するニッケ ルの結晶サイズを微細化することにより, $\mathrm{P}$ 種超硬合 金の抗折力とほぼ同じ比例限度応力を持つニッケル/

* 原稿受付 2006 年 7 月 28 日.

*1 正員, 福岡工業大学工学部 ( $\mathbf{\$}$ 811-0295 福岡市東区和白東 3-30-1).

*2 福岡工業大学大学院工学研究科.

E-mail : senba@ fit.ac.jp
リン合金を造ることを試みた。

本論文では, 平均粒径が $4 \mu \mathrm{m}$ のダイヤモンド砥粒 を結晶サイズが $2 \mathrm{~nm}$ 以下のニッケル/リン合金で固 定化した, 極微粒ダイヤモンド電鋳工具の開発を行っ た.ダイヤモンド砥粒に対する熱エッチング(4)や, 電 鋳工具に対する熱処理を行うことにより，耐欠損性や 耐摩耗性に優れた極微粒ダイヤモンド電鋳工具を開発 することを試みた。

\section{2. 理 論的背景}

$2 \cdot 1$ 砥粒に対する熱エッチング＼cjkstart極微粒ダイヤ モンド電鋳工具の耐欠損性を増すためには, ダイヤモ ンド砥粒と砥粒を固定化するニッケル/リン合金との 結合力を上げる必要がある.しかし，ダイヤモンド砥 粒は化学的に不活性であり ${ }^{(5)}$, 化学的な手法で砥粒と ニッケル/リン合金との結合力を上げるのは難しい.

そこで, 砥粒を熱エッチング(4)することによって砥 粒の表面に微細な山凸を付け，この凹凸に結晶サイズ が $2 \mathrm{~nm}$ 以下のニッケル/リン合金を電析させること により，砥粒とニッケル/リン合金との物理的結合力 を上げることを試みた。

$2 \cdot 2$ 合金強化 ニッケル/リン合金めっきを行う と, 結晶成長点にリンが吸着してニッケルの結晶成長 
を抑えるため，非晶質なニッケル/リン合金を造るこ とができる，この，電気めっき法によって造られるニ ッケル/リン合金を加熱すると $300^{\circ} \mathrm{C}$ 付近の温度で $\mathrm{Ni}_{3} \mathrm{P}$ が生成され，合金の硬さが $1000 \mathrm{Hv}$ 程度にまで 増加する(6).

この $\mathrm{Ni}_{3} \mathrm{P}$ が非晶質なニッケル粒子の粒界に析出す る場合には, $\mathrm{Ni}_{3} \mathrm{P}$ が隣接する非晶質なニッケル粒子 を強固に結合する可能性があると考えられた。そこ で，試作したニッケル/リン合金製の極微粒ダイヤモ ンド電鋳工具に対して熱処理を行い, 工具母材の硬さ だけでなく, 電鋳工具の耐久損性やャング率を増加さ せることを試みた。

\section{3. 実 験 方 法}

$3 \cdot 1$ 砥粒に対する熱エッチング＼cjkstart砥粒の 3 層分 に相当する重量のダイヤモンド砥粒を磁器製の蒸発皿 に敷き詰め，砥粒に対する熱エッチングを行った．平 均粒径が $4 \mu \mathrm{m}$ (メッシュサイズが\#3000)のダイヤモ ンド砥粒を使用し，短時間で砥粒を熱エッチングでき る条件を見出すための実験を行った．エッチング後の 砥粒に付着した死分については，高温酸処理法(7)を用 いてこれを除去した。

$3 \cdot 2$ めっき液 めつき液には，ニッケル/リン合 金めっき液を使用した．高速めつき(3)を行うため, $\mathrm{pH}$ 緩衝剤にはクエン酸を使用した。また, ニッケル の結晶サイズが $2 \mathrm{~nm}$ 以下のニッケル/リン合金を造 るため, 微細化剂として使用した亜リン酸を $70 \mathrm{~g} / 1$ の 割合でめっき液に加えた。

$3 \cdot 3$ 電鋳工具製造装置 極微粒ダイヤモンド電 鋳工具を試作するために使用した，めつき装置の外観 を図 1 に示す. めっき液を入れるための水槽, ニッケ ル製の陽極，ステンレス製の陰極，ならびに陰極を回 転させるためのステッピングモータといった, 四つの

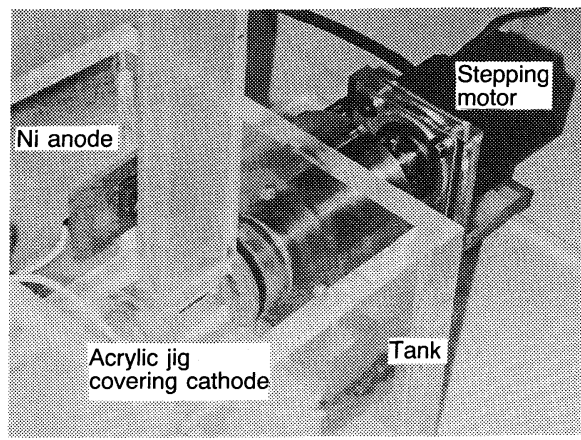

Fig. 1 Plating rig used for fabricating electroformed diamond tool using $\mathrm{Ni} / \mathrm{P}$ plating solution
主要部分で構成されている.

図 2 に陰極部の詳細を示している.ステンレス製の 陰極(1)をカバーするアクリル製カバー(2)には $2.5 \times$ $5 \times 20 \mathrm{~mm}$ の溝が成形されており, (2)は陰極と一体に なって回転する。めっき液に分散させた砥粒は外周を 親水性フィルタ(6)で覆ったアクリル製円筒(4)に入れら れており, (4)は水槽の壁に止められている.

したがって，陰極が回転する間に溝に入った砥粒は 電着, 埋込み，ならびに再分散され，ニッケル/リン合 金製の極微粒ダイヤモンド電鋳工具は上記の溝に沿つ て成長する，同装置を用いた上で陰極電流密度 ${ }^{(3)} 4$ $\mathrm{A} / \mathrm{dm}^{2}$ に設定すると，ダイヤモンド砥粒を含まない $2.5 \times 2.5 \times 20 \mathrm{~mm}$ の短冊状ニッケル/リン合金を 123 時間で造ることができる.

$3 \cdot 4$ 電鋳工具の比例限度応力とヤング率 試作 した短冊状の極微粒ダイヤモンド電鋳工具を直径が $0.5 \mathrm{~mm}$ の円柱状に成形した後, 片持ばり方式での曲 げ試験を行った。電鋳工具の円柱成形にはメタルボン ドダイヤモンドホイール SD 500 P 100 MW 5 を使用 した。

曲げ試験の結果を式 (1)や式 ( 2 )に代入することに より, 電鋳工具の比例限度応力 $\sigma_{e}$ やヤング率 $E$ を求 めた(3).

$$
\begin{aligned}
& \sigma_{e}=32 \cdot W_{e} \cdot L /\left(\pi \cdot d^{3}\right) \cdots \cdots . \\
& E=64 \cdot W_{e} \cdot L^{3} /\left(3 \pi \cdot d^{4} \cdot \delta_{e}\right)
\end{aligned}
$$

ここで, $W_{e}$ は比例限度荷重, $\delta_{e}$ は $W_{e}$ に対応する曲 げ変位, $L$ は電鋳工具の長さ, ならびに $d$ は円柱状に 成形した電鋳工具の直径である.

$3 \cdot 5$ 電鋳工具に対する熱処理の条件 極微粒ダ イヤモンド電鋳工具に対する熱処理の条件を決めるた め, ニッケル/リン合金に対する熱処理を行った。図 1 の装置を使って試作した短冊状のニッケル/リン合金
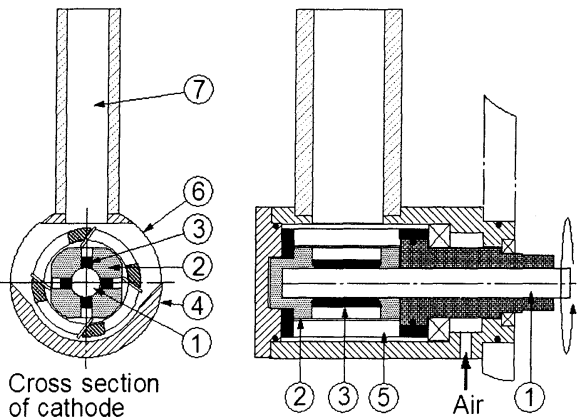

Fig. 2 Schematic view near cathode (1)cathode, (2) acrylic insulator, (3)electroformed tool, (4)cylindrical acrylic jig, (5)stirring blade, (6hydrophilic filter, (7)slit) 
に対して熱処理を行った後, 表面を平坦に研磨した同 合金に対して硬さ試験，円柱状に成形した同合金に対 して曲げ試験を行った。

熱処理を行うに際しては, ニッケル/リン合金に取 り込まれた水素を除去するためのべーキング(8) と, 同 合金を合金強化するための熱処理とを併せて行った. ベーキング温度/保持時間は $190^{\circ} \mathrm{C} / 3$ 時間に設定した。 合金強化のための熱処理では，保持時間を 1 時間に固 定した上で熱処理温度を変化させ, 最適な熱処理温度 を見出すための実験を行った.

極微粒ダイヤモンド電鋳工具に対しても, 短冊状の 電鋳工具に対してベーキングや合金強化のための熱処 理を行った後, 円柱状に成形した電鋳工具に対して曲 げ試験を行った。

\section{4. 実 験 結 果}

$4 \cdot 1$ 砥粒に対する熱エッチング＼cjkstart熱エッチング した砥粒の重量減と保持時間との関係を図 3 に示す. 炉に入れることができる蒸発皿の寸法の関係で, 一度 にエッチングできる砥粒の重量は $2 \mathrm{~g}$ 程度であった。

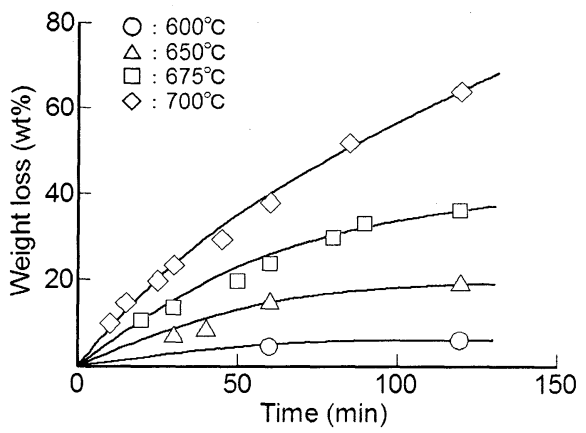

Fig. 3 Weight loss of thermally etched diamond grains of \# 3000 mesh size

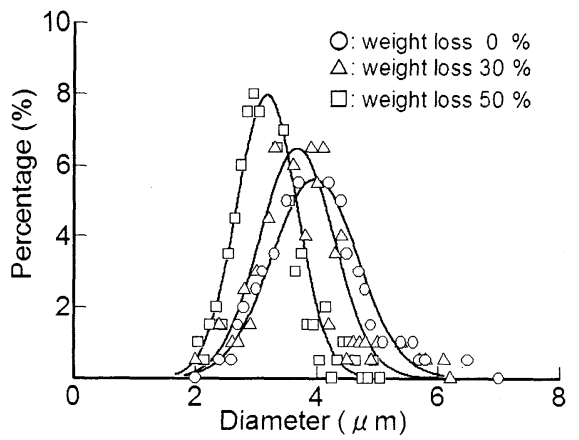

Fig. 4 Variation of grain size distribution of thermally etched diamond grains of \# 3000 mesh size
これに対し，電鋳工具を造るためには最低でも $20 \mathrm{~g}$ の砥粒が必要であった。そこで, 砥粒の熱エッチング に要する時間を短縮化するため，エッチング温度は $700^{\circ} \mathrm{C}$ に決定した。

エッチング温度を $700^{\circ} \mathrm{C} に$ 固定した上で保持時間を 変え, 重量減が $30 \mathrm{wt} \%$ ならびに $50 \mathrm{wt} \%$ になるよう に熱エッチングされた砥粒の粒度分布を図 4 に示す. 熱エッチングしない砥粒の中心粒径は $4 \mu \mathrm{m}$ であっ た.これに対し, 砥粒の重量減が $30 \mathrm{wt} \%$ の場合には $3.7 \mu \mathrm{m}$, 重量減が $50 \mathrm{wt} \%$ の場合には $3.2 \mu \mathrm{m}$ に中心 粒径が減少していた。

図 5 に砥粒表面の SEM 写真を示したように，砥粒 の重量減が $30 \mathrm{wt} \%$ の場合に比べて $50 \mathrm{wt} \%$ の場合に は，砥粒が過度にエッチングされた印象があった。そ こで,エッチング温度/保持時間を $700^{\circ} \mathrm{C} / 45$ 分に設定 し，重量減が $30 \mathrm{wt} \%$ になるうな砥粒を製作した。

$4 \cdot 2$ 砥粒に対する熱エッチングの効果＼cjkstart熱エッ チングしたダイヤモンド砥粒を使用し，極微粒ダイヤ モンド電鋳工具を試作した。この場合，めっき液に分 散させる砥粒の濃度を上げることにより電鋳工具の砥 粒率を増加させることにした。

試作した電鋳工具に関する比例限度応力と砥粒率と の関係を図 6 ; ヤング率と砥粒率との関係を図 7 に示 す．比較のため, P 種の超硬合金に関する抗折力 ${ }^{(9)} を$ 斜線, 熱エッチングしていない通常の砥粒を用いて試 作した電鋳工具に関する比例限度応力やヤング率を黒 印で付記した。

砥粒率を変化させた各場合とも，通常の砥粒を用い た場合に比べ熱エッチングした砥粒を用いた場合に は, ヤング率を $10 \mathrm{GPa}$ 程度, 比例限度応力を 500 $\mathrm{MPa}$ 程度, 増加させることができた。

$4 \cdot 3$ 電鋳工具母材に対する熱処理 砥粒を共析 させていない, 熱処理後のニッケル/リン合金に関す

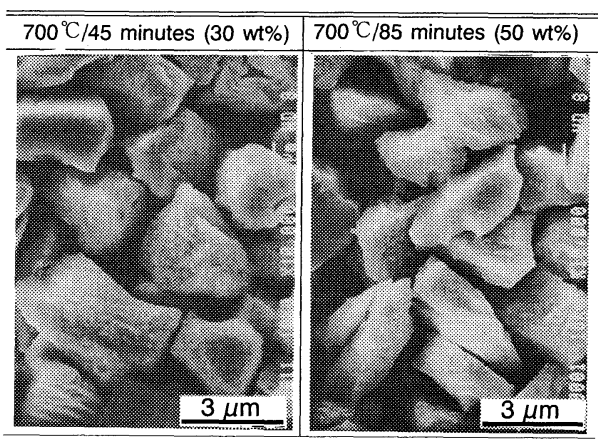

Fig. 5 SEM view of thermally etched diamond grains, 10 and $30 \mathrm{wt} \%$ in weight loss, respectively 
る硬さ試験の結果を図 8 , 曲げ試験の結果を図 9 に示 す.すでに報告されている実験の結果 ${ }^{(6)}$ と同様に, $300^{\circ} \mathrm{C}$ 以上の温度で熱処理を行うとニッケル/リン合金 の硬さは $1000 \mathrm{Hv}$ 程度まで増加することが確かめら れた. 一方, $300^{\circ} \mathrm{C}$ 以上の温度で熱処理を行うと, 比例 限度応力は急激に減少することが明らかになった。

図 8 や図 9 の現象を解明するため, X 線回折法によ る同定分析を行った. 熱処理後のニッケル/リン合金 に関する X 線回折の結果を図 10 に示す. $190^{\circ} \mathrm{Cでべ}$ ーキングを行った試料からは非晶質体特有のハローな

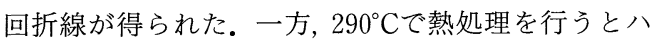
ローな回折線の上に $\mathrm{Ni}_{3} \mathrm{P}$ のシャープな回折線が重な った分布が得られた。 なお, $400^{\circ} \mathrm{C}$ 以上の温度で熱処 理を行うとハローな回折線はほぼ消滅し, $\mathrm{Ni}_{3} \mathrm{P}$ のシ ヤープな回折線のみが観察された。

したがって, 図 9 に示したように比例限度応力が $300^{\circ} \mathrm{C}$ 付近で最大になったのは, リンが吸着している 非晶質なニッケル粒子の粒界に $\mathrm{Ni}_{3} \mathrm{P}$ が析出し, これ が隣接する非晶質なニッケル粒子を強固に結合する役 割を果たした可能性が高い. なお, $300^{\circ} \mathrm{C}$ 以上の温度

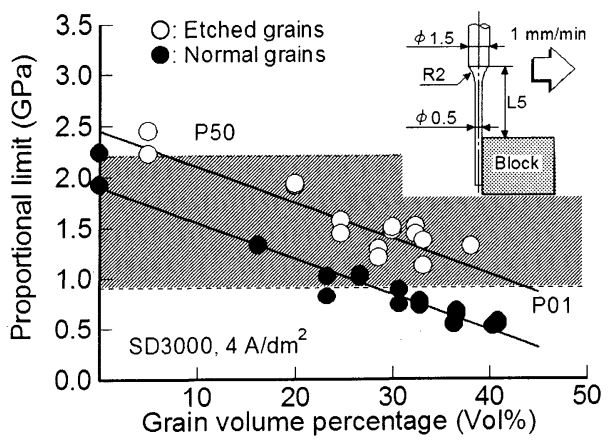

Fig. 6 Proportional limit of electroformed diamond tools obtained using thermally etched grains

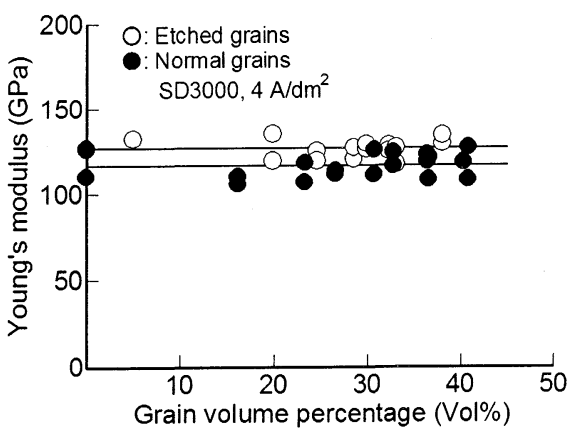

Fig. 7 Young's modulus of electroformed diamond tools obtained using thermally etched grains
で比例限度応力が減少したのは, $\mathrm{Ni}_{3} \mathrm{P}$ の結晶粒が再 結晶する過程で粗大化したためである(6).

図 8 や図 9 の実験結果を踏まえ, 極微粒ダイヤモン ド電鋳工具に対する熱処理温度/保持時間は $290^{\circ} \mathrm{C} / 1$ 時間に決定した。

$4 \cdot 4$ 電鋳工具に対する熱処理の効果＼cjkstart熱エッチ ングしていない通常の砥粒を用いて極微粒ダイヤモン

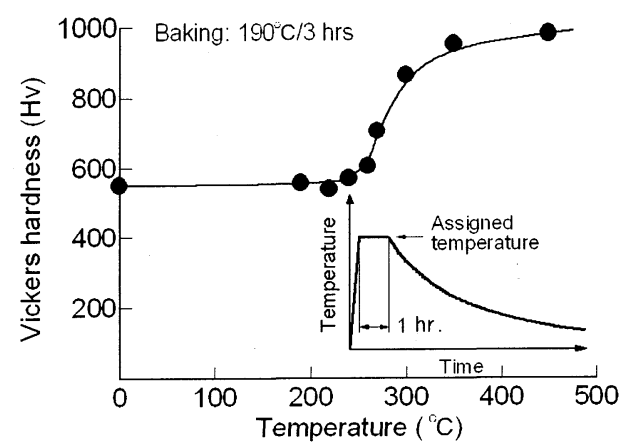

Fig. 8 Micro-Vickers hardness of electrodeposited Ni/ $\mathrm{P}$ alloy obtained by varying annealing temperature

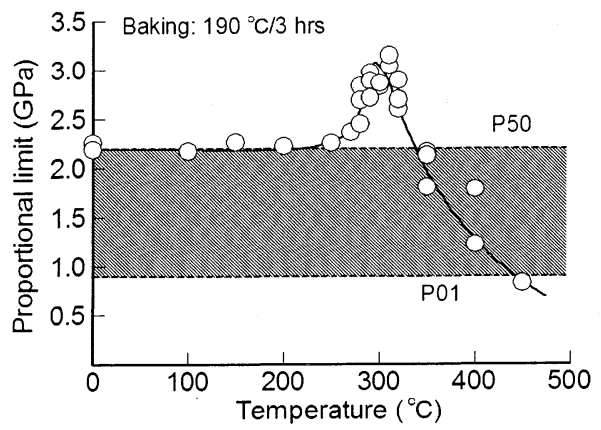

Fig. 9 Proportional limit of electrodeposited $\mathrm{Ni} / \mathrm{P}$ alloy obtained by varying annealing temperature

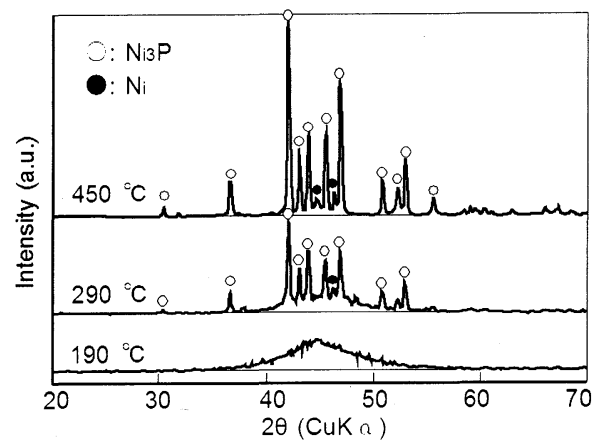

Fig. $10 \mathrm{X}$-ray diffraction profiles of electrodeposited $\mathrm{Ni} / \mathrm{P}$ alloy measured at various annealing temperatures 
ド電鋳工具を試作した後, 電鋳工具に対する熱処理を 行った.この, 熱処理を行った電鋳工具に関する比例 限度応力と砥粒率との関係を図 11 , ヤング率と砥粒率 との関係を図 12 に示す. 比較のため, 熱処理をして いない電鋳工具に関する比例限度応力やヤング率を図 11 や図 12 に黒印で付記した。

砥粒率を変化させた各場合とも, 電鋳工具を熱処理 しなかった場合に比べ熱処理した場合には, ヤング率 を $25 \mathrm{GPa}$ 程度, 比例限度応力を $500 \mathrm{MPa}$ 程度, 増加 させることができた。

$4 \cdot 5$ 砥粒と電鋳工具に対する熱処理の効果 熱 エッチングした砥粒を用いて極微粒ダイヤモンド電鋳 工具を試作した後, 電鋳工具に対する熱処理を併せて 行った. 試作した電鋳工具に関する比例限度応力と砥 粒率との関係を図 13, ヤング率と砥粒率との関係を図 14 に示す. 比較のため, 砥粒に対する熱エッチングや 電鋳工具に対する熱処理をしなかった場合に得られた 実験の結果を図 13 や図 14 に黒印で付記した。

砥粒に対する熱エッチングや電鋳工具に対する熱処 理をしなかった場合に比べ, 両方の熱処理を併せて行

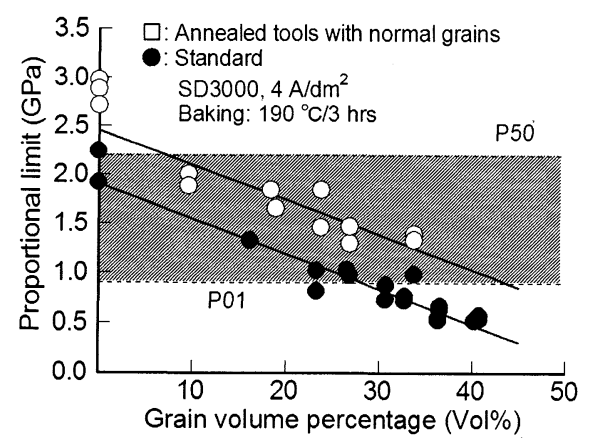

Fig. 11 Proportional limit of electroformed diamond tools obtained by annealing tools

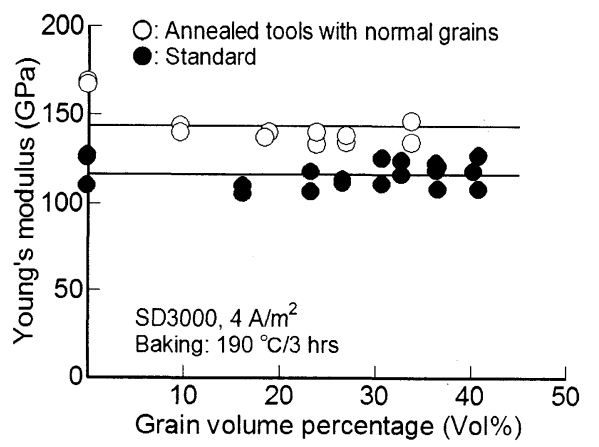

Fig. 12 Young's modulus of electroformed diamond tools obtained by annealing tools
つた場合にはヤング率を $40 \mathrm{GPa}$, 比例限度応力を 1 $\mathrm{GPa}$ 程度, 増加させることができた。

$4 \cdot 6$ まとめ 市販の電着工具の製造に用いられ ている, 光沢ニッケルめっき液を用いた場合について も極微粒ダイヤモンド電鋳工具を試作し, 電鋳工具に 対する曲げ試験を行った。通常の砥粒を用いて試作し た電鋳工具に関する比例限度応力と砥粒率との関係を 図 15 , ヤング率と砥粒率との関係を図 16 に示す. 比 較のため, めっき液をニッケル/リン合金めっき液に 変えた場合の結果を $\triangle$ 印, めっき液をニッケル/リン 合金めっき液に変えた上で，砥粒に対する熱エッチン グや電鋳工具に対する熱処理を併せて行った場合の結 果を○印で示している.

光沢ニッケルめっき液を用いた試作したダイヤモン ド電鋳工具に比べ，めっき液をニッケル/リン合金め つき液に変えた上で砥粒に対する熱エッチングや電鋳 工具に対する熱処理を併せて行うことにより，ヤング 率を $40 \mathrm{GPa}$ 程度, 比例限度応力を $1.5 \mathrm{GPa}$ 程度, 増 加させることができた.

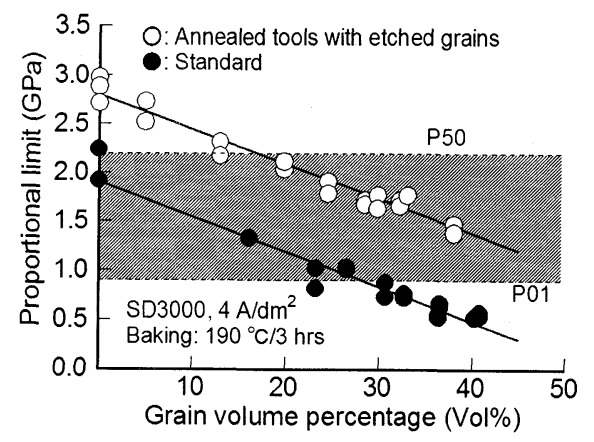

Fig. 13 Proportional limit of electroformed diamond tools obtained by annealing tools and using thermally etched grains

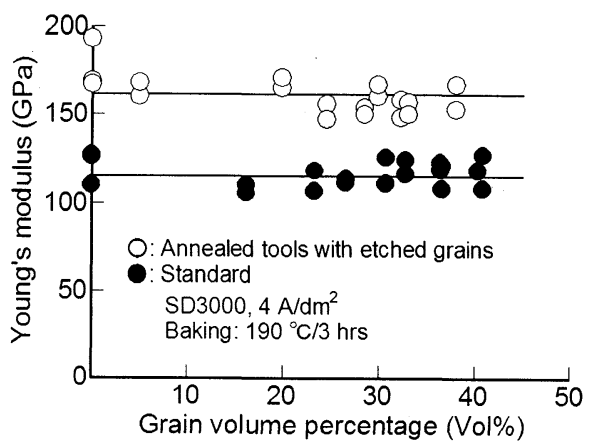

Fig. 14 Young's modulus of electroformed diamond tools obtained by annealing tools and using thermally etched grains 


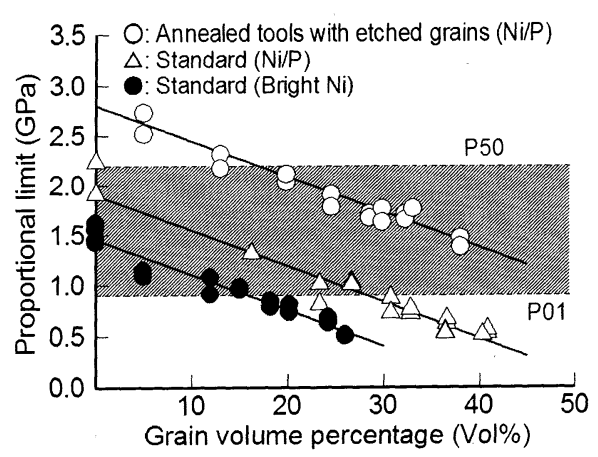

Fig. 15 Proportional limit of electroformed diamond tools obtained by changing plating solution, annealing tools and using thermally etched grains

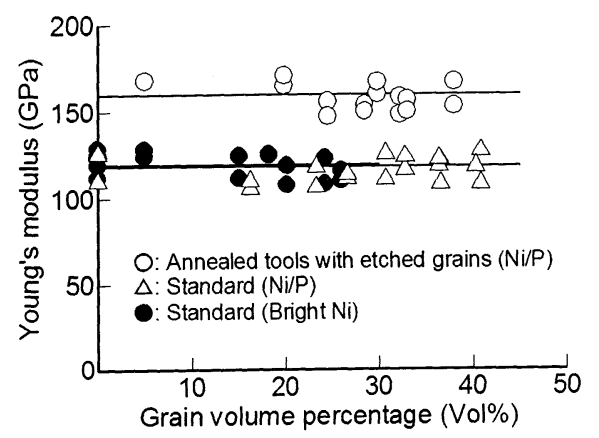

Fig. 16 Young's modulus of electroformed diamond tools obtained by changing plating solution, annealing tools and using thermally etched grains

このように，極微粒のダイヤモンド砥粒に対する熱 エッチングや, 電気めっき法を用いて試作したニッケ ル/リン合金製の極微粒ダイヤモンド電鋳工具に対す る熱処理は, 電鋳工具の耐欠損性, 耐摩耗性ならびに ヤング率を増加させるのに有効であることが確かめら れた。

\section{5. 結言}

ダイヤモンド砥粒に対する熱エッチングや電鋳工具 に対する熱処理を行うことにより，耐欠損性や耐摩耗 性に優れた極微粒ダイヤモンド電鋳工具を開発するこ とを試みた。本論文で得られた研究の成果は, 以下の ようにまとめられる。
（1）電鋳工具の母材として使用した，ニッケル/ リン合金に対して $290^{\circ} \mathrm{Cで} 1$ 時間の熱処理を行うこと により, 合金の硬さを $580 \mathrm{Hv}$ から $800 \mathrm{Hv}$, 比例限度 応力を $2 \mathrm{GPa}$ から $3 \mathrm{GPa}$ ，ならびにヤング率を 120 $\mathrm{GPa}$ から $170 \mathrm{GPa}$ に増加させることができた。

（2）重量減が $30 \mathrm{wt} \%$ になるように砥粒を熱エッ チングして表面に微細な凹凸を付けたダイヤモンド砥 粒を用いた場合には，通常の砥粒を用いて試作した電 鋳工具に比べ, ヤング率を $10 \mathrm{GPa}$ 程度, ならびに比 例限度応力を $500 \mathrm{MPa}$ 程度, 増加させることができ た.

（3）熱エッチングした砥粒を用いて試作した電鋳 工具に対して $290^{\circ} \mathrm{C} て ゙ 1$ 時間の熱処理を行った場合に は，通常の砥粒と光沢ニッケルめっき液を用いて試作 した電鋳工具に比べ, ヤング率を $40 \mathrm{GPa}$ 程度, なら びに比例限度応力を $1 \mathrm{GPa}$ 程度, 増加させることがで きた。

\section{文献}

(1) Sawada, K. et al., Improvement of Ultraprecision Micromachining Accuracy by Means of a High Precision Tool Chucking System, Proceedings of CIRP International Seminar on "Improved Machine Tool Performance" (1998-7), pp. 599-606, San Sebastian.

(2) Onikura, H. et al., Fabrication of Ni-W Electroplated Micro Diamond Grinding Tools and Their Application to Grooving in Silicon, Proceedings of the Third Inter. national Conference in LEM21, Vol. 3 (2005-10), pp. 1241-1246.

(3) Senba, T. and Kasa, Y., Development of High-Speed Electroforming Technique for Fabricating Microgrinding Tool, Transaction of the JSME, Series C, Vol. 70, No. 694 (2004), pp. 311-316.

(4) Yoshikawa, M., Surface Modification of Diamond Grains, Handbook of Synthesised Diamond Technology (in Japanese), (1989), pp. 388-395, Sience Forum.

(5) Novikov, N. B. et al., Synthesis of Diamond (in Japanese), (1993), p. 91, Ohm.

(6) Hasegawa, K. et al., The Increase in Hardness of Electroplated Ni-P Films with Heating, Journal of the Surface Finishing Society of Japan, Vol.40, No. 3 (1989), pp. 65-70.

(7) Makita, H., Ultra Fine Diamond Particles, Journal of the Surface Finishing Society of Japan, Vol. 47, No. 11 (1996), pp. 20-24.

(8) Murayama, K. and Mohri, H., Plating Words Dictionary (in Japanese), (1994), pp. 429, Nikkankogyo.

(9) JSMEed., JSME Mechanical Engineers' Handbook, B 4, (1984), B 4-95, Toppan.

(10) Masui, K. et al., Heat-Inducted Structural Changes in Electroplated Ni-P Alloys, Journal of the Japan Institute of Metals, Vol. 41, No. 11 (1977), pp. 1130-1136. 